\title{
Discussion on the Fairness of "Private School with Public Assistance" Education Policy of Macaoin the Context of Industrialization
}

\author{
Shaodan $\mathrm{Su}^{1,2}$,Hongfeng Zhang $^{{ }^{*}}$ \\ ${ }^{1}$ School of Humanities and Social Sciences,Macao Polytechnic Institute,Macao,999078; \\ ${ }^{2}$ Foshan University, Foshan, Guangdong,528000, China \\ *Corresponding author.
}

\begin{abstract}
The "PrivateSchool with Public Assistance" Education Policy of Macao is implemented with strong financial support from the government.Rawls' "Justice" thought contains ideological connotations such as equal freedom, fair opportunity, and difference principles. The two justice principles proposed by Rawls have profound value enlightenment for the adjustment of interests and the reconciliation of contradictions in social issues. In Macau, the industrial manufacturing industry is relatively lacking. The development of tourism and gaming industry has accumulated a solid financial foundation for Macau. Currently, the basic education in Macau presents a pattern in which private schools are the mainstay. The government's subsidy policy for private schools can be inspired by Rawls's "Justice" thoughts to think about achieving equal educational opportunities, fair resource allocation, and differentiated adjustment of distribution standards.
\end{abstract}

Keywords: Justice, fairness, education, policy, manufacture

\section{I.Introduction}

In 1971, the famous American philosopher and ethicist Rawls published his work "A Theory of Justice", which caused a huge sensation in Western academic circles and became a pivotal classic of political science, philosophy and ethics. In the middle of the 20th century, a crisis of trust in the West appeared, and the turbulent society had an urgent need for new values and beliefs. Based on the special background of the times, "On Justice" conducts an in-depth discussion on social justice issues. It covers a wide range of fields, responds to social issues and people's concerns, and has attracted widespread attention. Habermas called it an epoch-making masterpiece with the meaning of "a pivotal turning point".

\section{II.Question Raised}

"A Theory of Justice" discusses issues such as equal freedom, fair opportunity, distribution gap, and the principle of difference, etc., in a virtual or abstract way, put forward some suggestions and hopes to solve the problem. Although its value concept has a strong idealistic color, the discussion of social issues, system construction, and policy formulation and adjustment provide the direction of thinking and the standard for realization. The development process of basic education in Macao has shown a typical pattern internationally due to special historical conditions. Historically, during the period when the Macau-Portuguese government governed Macau, it ignored Macau's education. Churches, Chinese associations and people with lofty ideals struggled to explore under the special circumstances of the times, founded schools, and gradually created a pattern where private schools accounted for the majority of basic education in Macau. Since the issuance of Law No. 11/77/M in 1977, "Proper Support for Non-Profit Educational Undertakings", the Portuguese government has gradually assumed the public education function. In this law, the important position of private schools in education is recognized, and it is proposed: "Private educational establishments, especially the services provided by their teaching staff, should be recognized as having a public welfare nature, because it not only expands and supplements the administrative. The authorities are responsible for the education work and bring the benefits of education to all people."[1] After the signing of the Sino-Portuguese Joint Declaration on the Question of Macao in 1987, the process of formulating and improving the

ISSN: 0010-8189

(C) CONVERTER 2020 
"Private School Public Assistance" policy for basic education in Macao has accelerated. In 1999, Macao returned to the motherland. With the stable political environment after the return and the rapid economic take-off after the opening of Macao's gaming operation rights, Macao's "Private School Public Assistance" policy has gradually increased in funding breadth and intensity. In this process, the pattern of private schools occupying the main body of basic education in Macau remains. At present, in basic education in Macau, there are 74 formal education schools, including 10 public schools and 64 private schools. Private schools account for $86.49 \%$ and private school students account for $96.39 \%$. (table I). In the process of gradual improvement and adjustment of the government's funding policy for private schools, fairness and justice are important values. However, in the implementation of the policy, the fairness of the policy aroused consideration from different angles. The equality of educational opportunities, the fairness of the distribution of educational resources, and the differences in resource acquisition among different stakeholders are all discussed around the values of equality, fairness, and justice. This is in line with Rawls's "Justice". Corresponding to the core ideas. In-depth analysis and discussion of the value meaning of the "On Justice" thought is of inspiring significance for the reflection on Macau's "private school public assistance" policy.

Table1Table of Distribution of Basic Education in Macau

\begin{tabular}{|l|c|c|c|c|c|c|}
\hline \multicolumn{2}{|c|}{ School nature } & $\begin{array}{c}\text { Number of } \\
\text { schools }\end{array}$ & \multicolumn{2}{c|}{$\begin{array}{c}\text { Number of } \\
\text { students }\end{array}$} & \multicolumn{2}{c|}{ Percentage } \\
\hline \multirow{3}{*}{$\begin{array}{c}\text { Non-prof } \\
\text { it }\end{array}$} & Public & 10 & 2903 & 2903 & $13.51 \%$ & $3.61 \%$ \\
\cline { 2 - 5 } & $\begin{array}{c}\text { Free } \\
\text { private }\end{array}$ & 58 & 70339 & & & $87.42 \%$ \\
\cline { 2 - 5 } & $\begin{array}{l}\text { Non-free } \\
\text { private }\end{array}$ & 5 & 5880 & 77560 & $86.49 \%$ & $7.31 \%$ \\
\hline Profit & Private & 1 & 1341 & & & $1.67 \%$ \\
\hline Total & $/$ & 74 & 80463 & 2903 & 100 & $100 \%$ \\
\hline
\end{tabular}

\section{III.The Ideological Connotation of Rawls' Justice Thought}

Rawls" "On Justice" is a logical and speculative ideological system, which is mainly composed of two basic components. One is the two principles of justice, and the other is the basic idea of justice theory. "In Rawls' justice theory, the two justice principles are at the top of the theoretical system, and the things that support the two justice principles are the basic ideas of these justice theories."'[2].

According to Rawls's argument, it is assumed that under the conditions of the original state, people will unanimously choose two principles of justice: "The first principle of justice: everyone has a similar freedom system compatible with the most extensive and equal basic freedom system that everyone has. All should have a kind of equal power (the principle of equality and freedom); the second principle of justice: social and economic inequality should be arranged in such a way that they: (1) In accordance with the principle of justice, they are suitable for the least benefit. The best interests of the individual (the principle of difference); (2) it depends on the openness of the position and status to all people under the condition of fair and equal opportunities (the principle of fairness and equal opportunity)".[3] Two principles of justice, in a nutshell, one is the principle of equality and freedom, the other is the principle of equality of opportunity and the principle of difference. On this basis, Rawls proposed that in the face of possible conflicts between the principles of justice, the two "priority principles" of the principles of justice should be followed: the first principle of priority is that the first principle of justice takes precedence over the second. The principle of justice, that is, equality and freedom have priority over the principle of equality of opportunity and difference; the second principle of priority is that the principle of equality of opportunity in the second principle of justice has priority over the principle of difference. The ideological core contained in the two justice principles is the basic idea of Rawls's justice theory.

\subsection{Freedom and equality}


Rawls puts forward that "human nature is a free and equal rational existence". Man is free, which means that man is not dominated by external objective necessity, but has the ability to choose freely; man is equal, in Rawls's view, man is in social cooperation, everyone is a equal member in cooperation. This equality means that people perform and abide by corresponding rights and obligations equally in cooperation. From the perspective of moral philosophy, the idea of freedom and equality is embodied as the free will and purpose of human beings as rational beings, and from the perspective of political philosophy, it is embodied as equality and freedom related to political rights, legal system, political participation, belief, etc.

\subsection{Fair chance}

Fair opportunity is another ideological proposition of Rawls. According to its argument, "the position and status are open to all under the condition of fair and equal opportunity", which is equal opportunities in public positions in the field of public politics. The extension of this idea to other fields reflects that everyone as a member of society has a fair opportunity in the acquisition of public resources. What fair opportunity embodies is the fair opportunity principle in the second principle of justice, and it is also the embodiment of the concept of equality.

\subsection{Difference principle}

The greatest benefit of the least beneficiary is the core proposition of the difference principle. In Rawls's justice principle, the difference principle is concerned with fairness in the field of social distribution. In Rawls' view, society is a fair cooperative system in which people are mutually beneficialof. This is different from the pure self-interest emphasized byutilitarianism. The difference principle embodies the reciprocity in social cooperation.It is the value proposition of the difference principle to take care of the disadvantaged groups in order to achieve the balance of everyone's interests and the justice and long-term stability of the society.

The principle of justice and the thoughts contained therein are an organic whole that revolves around freedom and equality. The principles of freedom, equality, fair opportunity and difference have realized the value propositions of liberalism on freedom, equality and fraternity. The idea of freedom corresponds to the idea of freedom and the principle of freedom first in the first principle; the idea of equality corresponds to the idea of equality in the first principle and the principle of opportunity justice in the second principle; the idea of fraternity corresponds to the principle of difference in the second principle. As the guiding ideology of a well-ordered society, the principle of justice has important enlightening value in social distribution and benefit coordination.

\section{IV.The Enlightenment of Rawls' Justice Thought on “Private School Public Assistance” Policy}

\subsection{The development of free education policy:the reflection of the equal value of educational opportunities}

The equal right to education is an extension of citizens' right to political equality in the field of education. The 26th paragraph of the "United Nations Joint Declaration" stipulates: Regardless of social class and economic conditions, everyone has the right to education. Due to the particularity of historical conditions and changes in economic and political conditions, the development of basic education in Macau has shown phased changes in the protection of educational opportunities.

In the era of Portuguese government governance, basic education was ignored by the government. Basic education resources were only for Portuguese school children, and public education resources were invested in a very small number of public schools. Private schools, which account for the vast majority of basic education, were founded by churches and Chinese associations. School funding and educational resources were raised by the private sector. The stability of private schools was weak and the educational opportunities of Chinese students were not guaranteed. For 400 years, the differences in public and private schools that have received government attention, and the unequal education rights between public and private students have manifested the injustice and inequality of opportunity. Rawls' theory of justice states that people are equal, and equality is not only equality in moral personality, but also

ISSN: 0010-8189 
equality in political rights. The fairness of the right to education should not be differentiated due to differences in economic, political, and cultural conditions.

Educational policies are adjusted with changes in the political environment and economic conditions. Since 1977, the Portuguese government issued the "Proper Support for Non-Profit Educational Undertakings", it has gradually paid attention to basic education undertakings in Macau and provided appropriate support to private schools. After the signing of the Sino-Portuguese Joint Declaration on the Question of Macao in 1987, the basic education policy has continuously increased the support for private schools, and the free education policy has developed rapidly. In 2006, the Macao SAR government promulgated Law No. 9/2006 "Macao Non-Higher Education Outline Law” (referred to as the "Outline Law"), marking the full implementation of the 15-year free education policy in Macao. Article 21 of the "Outline Law" states: "Free refers to the exemption of tuition, supplementary service fees and other fees related to registration, attendance and certification. The beneficiaries of free education are those who are studying in the following areas and are residents of the students of Macao SAR government: (1) All grades within the scope of free education in public schools; (2) Private schools within the free education tuition system implement free education grades". [5] The amount of funding also shows a trend of increasing year by year. For 2020/2021, the amount of funding is shown in Table II. The free education policy guarantees the right to education of Macao's school-age children and fair educational opportunities provide institutional norms and guarantees. Opportunity justice is the core of Rawls'justice theory. In the process of formulating, implementing and improving education policies, opportunity justice is a basic requirement. The unfair starting point and the high and low thresholds will inevitably lead to the instability of the "infrastructure" of the education policy. The value basis of justice determines the firmness and authority of policies. In Macau, in the special situation where private schools account for the overwhelming majority of basic education, the value concept of equal educational opportunities should run through the formulation and improvement of education policies, which is the basis for stabilizing the educational order.

\subsection{Adjustment of the distribution of educational resources in public and private schools:the principle of fairness}

Fairness is the core of Rawls's justice thought. In Rawls's view, fairness is not only an important part of social ideals, but also a means to regulate social conflicts of interests. Therefore, fairness is both a purpose and a means. In practical social issues, the principle of fairness is always an important value guide and adjustment method. The principle of fairness puts forward requirements for reasonable distribution. "The living space and resources of human beings are limited, and human desires are unlimited. Every member of society wants more benefits, and the limited resources are not enough for distributing, and it is impossible to assign as needed, this requires certain rules to be specified in order to achieve a fair and reasonable distribution."[4] At present, the government's differences in the distribution of educational resources between public schools and private schools as shown by the basic education policies of Macau should lead to reasonable distribution of educational resources. "Educational equity is embodied in the field of education policy in that everyone equally enjoys public educational resources"[6].

Compared with private schools, public schools in Macau can enjoy greater financial support from the government. This is a gap that has formed during the administration of the Portuguese government in Macau. This situation has historical reasons. With the gradual formation of a modern education system in Macao after the return to the motherland, the social status of private schools has also been improved, and the government has continuously increased its funding. However, there is still a big gap in the educational resources enjoyed by public and private schools.

Table2 Table of free education allowances for different stage in the 2020/2021 school year

\begin{tabular}{|c|c|}
\hline Educational stage & Free education allowance (MOP) \\
\hline Kindergarten stage & 1063800 \\
\hline primary school & 1159100 \\
\hline junior high school & 1396800 \\
\hline High school & 1584300 \\
\hline
\end{tabular}

ISSN: 0010-8189 
Rawls puts forward: "The principle of justice is the result of a fair agreement or contract." This means that compliance with the principle of fairness in social distribution is a requirement for social justice and a basic criterion for a good social order. Public schools and private schools, as different stakeholders, are the objects of social resource allocation, and the actual users of resources are students and teachers. The issue of fairness in the distribution of resources in public and private schools.In fact, the issue of the fairness of resources enjoyed by students and teachers, ultimately returns to the issue of equality and good for people. Everyone engaged in social cooperation in a fair social system is an equal member and has his or her pursuit of basic good. On the one hand, people pursue interests; on the other hand, they are constrained by justice because of being a rational person. In real social issues, the constraints of justice are reflected in the principles of justice in systems and policies. If the allocation of public and private school resources ignores the principle of fairness, from the perspective of moral philosophy, it violates the ideological value that people are free and equal. Students and teachers in public and private schools cooperate in the social community. The activities of "teaching" and "learning" between teachers and students are essentially acting as both "teacher" or "student". The social role of people should be treated fairly and supported by corresponding resources. From the perspective of political philosophy, it weakens the manifestation of equality of rights and obligations in the field of education. Laws, regulations, and institutional policies provide norms and guarantees for everyone to enjoy the right to education. This is a manifestation of institutional fairness, and the realization of institutional fairness falls on the actual enjoyment of resources. The unfair distribution of resources in public and private schools is contrary to the requirements of institutional fairness, which has caused problems such as uneven education development among schools, conflicts between the government and private schools, and between public and private schools. Therefore, in the distribution of educational resources, the fairness principle of Rawls's justice thought is reflected. Fairness makes people's equal moral personality respected, fairness makes social resources reasonable distribution, and fairness makes the pursuit of interests restricted by justice norms. "If there is an inequality in the basic structure of society that can make everyone better than the original equality, why not allow this inequality?'[7]

\subsection{Adjustment of the distribution standard of private school education allowance: the principle of difference}

The difference principle of Rawls's justice theory is mainly reflected in the redistribution and adjustment of social, economic and political values. Its core proposition is to follow the principle of "the least beneficiary gets the most benefit" in the adjustment of the distribution of resources and benefits, to achieve social vertical fairness through differentiated distribution of benefits. In resource allocation, the principle of difference requires consideration of individual characteristics and different needs. The distribution of justice is based on fair competition conditions, that is, competitors will obtain the results of competition under equal starting points and fair opportunities. If the starting point is inconsistent and the opportunity is unfair, the result of the competition is unfair. The result is that "the larger the gap between the rich and the poor, the worse the condition of the poor, which violates the principle of mutual benefit and democratic equality."[8]In the discussion of the issue of educational equity, the principle of difference has become the reasonable redistribution of educational resources. "For education,thevulnerable groups with disadvantaged social and cultural conditions can get equal educational opportunities. This is achieved through differentiated educational resource allocation.Therefore, it manifests as a kind of vertical justice, embodying the principle of compensation for the vulnerable groups. "[9] However, The funding standard of Macau's "private school public assistance" policy is based on the "packaged class system", considering the fairness of the distribution standard, ignoring the vertical equity because of the individual differences.

Rawls's "Justice" thought revolves around the values of freedom, equality, fairness and other values and concerns about social reality. In the distribution of interests and contradiction adjustment in different fields, the principle of justice and its underlying ideas play an important role in inspiration. In the historical development of Macau's "Private School Public Assistance" policy, education equity is the core value goal. The government's funding of private schools has gone through four period: "indifferent", "appropriate funding", "intensified efforts" and "comprehensive". The pace of development of "funding", the protection of the right to education, and the fairness of educational opportunities are reflected in the formulation and improvement of Macao's education policy. However, in private school education subsidy funding, the allocation standard of the "package class system" ignores the

ISSN: 0010-8189 
individual differences among private schools, reflecting that the current "private school public assistance" cannot achieve substantive fairness. Rawls proposed that the distribution of justice should follow the principle of difference, take care of the weak, and avoid "the strong get stronger and the weak get weaker", which should also be applied in the distribution and adjustment of educational resources. Of course, it is undeniable that Macau's current "private school public assistance" policy model responds to the second priority principle of Rawls' justice principle: "Equal opportunity principle" takes precedence over "difference principle". Under the current financial foundation and social environment of Macau, the 15-year free education policy ensures the equality of educational opportunities, which reflects that the principle of fairness takes precedence over the principle of difference. Based on the satisfaction of fair opportunity and equality, the difference principle needs to be considered to promote the realization of substantive fairness. "In Rawls'view, the principle of justice allows everyone to freely enjoy equal rights and opportunities, while taking care of the interests of the smallest income earners, and trying to eliminate economic inequality to the greatest extent, to maintain social fairness and justice. It can unite individuals and society to achieve the ideal social state of freedom, equality, and harmony".[10]

Rawls' "Justice" thought can provide value for the improvement of Macau's "private school public assistance" policy and the adjustment of contradictions between different stakeholders. And it guides to promote social realization of distribution justice and education fairness. "The degree of democratization and scientific of educational policies ultimately depends on whether their educational policies reflect the interests of the relevant classes and the masses in a balanced and reasonable manner; if the relevant educational interests of different themes in society are not reflected in the educational policies, the conflict of interests will be conflicts cannot be coordinated in a timely and effective manner. No matter how powerful the management function of education policy is, it can only be the alienation of ends and means".[11]

\section{V.Conclusion}

Although Macau is a micro city, the construction process of its "private schoolpublic assistance" policy system and the contradictions and dilemmas that emerge from it have their typical characteristics, which are worthy of arousing deep thinking on the development of privatized education in different countries and regions. "To formulate education policies, we should thoroughly study the value needs and orientations of policy subjects and stakeholders, find out their common value needs and orientations at different levels, and reflect on whether the current government's value orientation is in line with policy subjects and interests. The value orientation of the stakeholders is consistent, whether they can meet their value needs". [12] "Education is still the form of expression of human nature and morality in our era. Therefore, no matter how it changes, education should abide by and develop a strong humanitarian spirit and make it a historical boost to promote the progress of human society." [9] Return the human value of education, facing up to the various contradictions in the development of private schools, weighing the demands of different stakeholders, and promoting the symbiotic development of educational fairness and efficiency, is the value choice for constructing a rational education policy.

\section{Acknowledgements}

This project is supported by Macao Polytechnic Institute(No. RP/ESCHS-01/2021).

\section{References}

[1] The Portuguese Government of Macau. No. 65/84/M. Several funding methods for non-profit-making private schools. Macau: Boletim Official De Macau, vol 27, pp. 1403, 1984.

[2] D.Z. Yao.“The Basic Ideas of Rawls' Theory of Justice. Social Science Research,” vol. 4, pp. 59-65, 2008.

[3] J.Rawls.A Theory of Justice. Beijing: China Social Sciences Press, pp.60-61, 1988.

[4] He Jupeng. (2009)The Harmonious Implication and Modern Reality of Rawls' Theory of Justice.qiusuo, (8),63-65.

ISSN: 0010-8189 
[5] Macau Government. No. 9/2006. Non-Higher Education System Outline Law. Macau: Official Bulletin of the Macau Special Administrative Region,vol. 52, pp. 1544, 2006.

[6] Q. Zhang,C.X. Sun, H. Zheng. "The value pursuit of education: fairness first and also pay attention to efficiency," Educational Exploration,vol. 1, pp. 1-5, 2020.

[7] J. Rawls. A Theory of Justice. Beijing: China Social Sciences Press, pp.150, 1988.

[8] Xu Lin. (2012) On the basis ofRawls' justice principles to realize the fair distribution of educational resources. Finance and Economics Research, (11),10-13.

[9] K.H. Lao."Ethical Issues in the Reform of Public Education System,"Educational Reacher, vol. 2, pp. 3-11, 2005.

[10] S.H. Zheng. "Review of Rawls'"On Justice",’Modern Educational Science, vol. 1, pp. 405-406, 2009.

[11] L.K. Li.Philosophical Axiology. Beijing:Published by Renmin University of China,pp. 83-84, 1991.

[12] J.H. Luo.“On the Multidimensional Perspectives of Educational Policy Research,"Educational Research, vol. 3, pp. 39-45, 2016. 